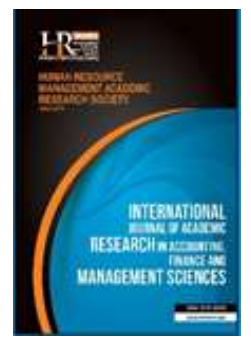

International Journal of Academic Research in Accounting, Finance and Management Sciences

Vol. 9, No.4, October 2019, pp. 49-56

E-ISSN: 2225-8329, P-ISSN: 2308-0337

(C) 2019 HRMARS

www.hrmars.com

To cite this article: Wijaya, R., Lutfi, Aulia, B. B. (2019). Influence of E-filing System Implementation against Taxpayer Compliance of the Submission the Annual Notice (SPT) by Understanding the Internet as Moderating Variable on Office Services Tax Pratama Jambi City, International Journal of Academic Research in Accounting, Finance and Management Sciences 9 (4): 49-56

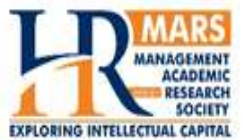

http://dx.doi.org/10.6007/IJARAFMS/v9-i4/6640 (DOI: 10.6007/IJARAFMS/v9-i4/6640)

\title{
Influence of E-filing System Implementation against Taxpayer Compliance of the Submission the Annual Notice (SPT) by Understanding the Internet as Moderating Variable on Office Services Tax Pratama Jambi City
}

\author{
Rico Wijaya ${ }^{1}$, Lutfi ${ }^{2}$, Aulia Beatrice B. ${ }^{3}$ \\ 1,2,3 Faculty of Economics and Business, University of Jambi, Jambi, Indonesia, \\ ${ }^{1}$ Email: ricowijaya1981@yahoo.com ; ${ }^{3}$ E-mail: auliabeatrice@gmail.com ;
}

\begin{abstract}
The research is aimed to prove the benefits of the policy E-filing system in mandatory taxes compliance and in particular look at the role of understanding the Internet in moderating of e-Filing system to the mandatory taxes compliance. The study method is using Moderated Regression Analysis, coefficient of determination, hypothesis testing using $t$ test, and classical assumption. Study sample of 100 respondents residing in the territory of Office Services Tax Pratama Jambi City. The statistical tool in this study uses WarpPLS version 4. Results of the study show e-filing system variable influence significantly positive towards compliance mandatory taxes. Understanding of the internet vvariable is not proven moderating the relationship E-filing system variable to mandatory taxes compliance. The results of this study were expected to make a small contribution to the Directorate General of Taxes regarding the ease of implementing the E-filing system, especially the ease of features available on the djponline.pajak.go.id website and information on tax benefits in the internet media increase compulsory tax compliance. This research is a reflection of previous studies, the difference are the object of research and the examined sample

Key words E-Filing System, Internet Understanding, Taxpayer Compliance

Received: 20 Nov 2019 (C) The Authors 2019

Revised: $\quad 30$ Nov 2019 Published by Human Resource Management Academic Research Society (www.hrmars.com)

Accepted: 05 Dec 2019 This article is published under the Creative Commons Attribution (CC BY 4.0) license. Anyone may Published Online: $\quad$ reproduce, distribute, translate and create derivative works of this article (for both commercial and non-commercial purposes), subject to full attribution to the original publication and authors. The full terms of this license may be seen at: http://creativecommons.org/licences/by/4.0/legalcode
\end{abstract}

\section{Introduction}

Taxes are supporting economic activities, driving the government, and providing public facilities. This must be realized by every citizen so that taxes obligations must be fulfiled. In the State Budget (APBN) about $70 \%$ is filled by tax revenue. Although taxes dominate the APBN, in reality this is still far from the potential that can be obtained. The government continues to increase the tax revenue target every year. Tax ratio Indonesia in 2018 relatively low, amounting to 11.6 \% (kemenkeu.go.id, 2018).

Based on data obtained from the Directorate General of Taxes, so far Indonesia is categorized as a lower middle income country that has a low tax ratio. The data in 2018 showed Indonesia was under the average tax ratio lower middle income countries that reached $17.7 \%$. When compared to other countries such as Thailand $15.7 \%$, Cambodia $15.3 \%$, Singapore 14.3\%, Malaysia 13.8\%, and the Philippines $13.7 \%$, Indonesia's tax ratio is still very low. 
To increase taxpayers compliance in Indonesia continue to be carried out, and the level continues to increase from year to year even though it is still considered very low. This condition is caused by the reluctance and unwillingness of taxpayers to report their tax obligations for various reasons. This is also supported by the level of taxpayer awareness and knowledge of tax regulations which still lacking. This is an obstacle that must be faced by the Directorate General of Taxes. The amount of tax revenue depends on the level of awareness of taxpayers to be orderly in paying taxes. The government making improvements in the tax reporting process by utilizing information and communication technology by implementing e-filing.

Based on the decision of the Director General of Tax no. Kep-88/PJ/2004 in May 2004 the Electronic Filing System product was officially launched. E-filling is a service for filing and submitting Taxpayer Tax Returns that were done electronically through a real-time online system to the Directorate General of Taxes through the internet on the website of the Directorate General of Taxes or through Application Service Providers that have been designated by the Directorate General of Taxes.

E-filing system expected in late provide comfort and convenience for taxpayers to prepare and submit tax returns because it can be delivered anytime and anywhere without the need to come to the tax office so as to minimize cost and time used for the calculation, filling and delivery of SPT. Although the efiling system has been made to facilitate the taxpayer to, but in reality there were many taxpayers who have not used it.

E-filling requires the application of the internet, therefore to use e-filling Taxpayers are required to be able to operate the internet. Based on the Indonesian Internet Service Providers Association in 2017, the total internet users in Indonesia grew slightly by almost 8 percent to 143.26 million people or $54.68 \%$ of the total population of 262 million people compared to the previous year of 132.7 million. The composition of the internet deployment, Java dominates amounting to 58.08\%, Sumatera (19.09\%), Kalimantan (7.97\%), Sulawesi (6.73\%), Bali-Nusa (5.63\%), and Maluku-Papua ( $2.49 \% \%$ ), while from the composition of users by age, the age range of 19-34 years was the main contributor with a percentage of $49.52 \%$, 35-54 years (29.55\%), 13- 18 years (16.68\%), and more than 54 years (4.24\%). From these users it can be concluded that internet users on the island of Sumatra are not a large percentage with internet users dominated by productive age groups.

Several previous studies on the effect of E-Filing on taxpayer compliance have been done by Suherman et al. (2015) the results show that E-Filing has no effect on compulsory compliance with the results of research conducted by Lado and Budiantara (2018) , Erawati and Ratnasari (2018) and Ismail et al. (2018) results it showed that the E- Filing an effect on the compliance of mandatory taxes In general there are inconsistencies in research relationships influence E-Filing of the compliance of taxpayers.

The internet is short for the word "interconnection-networking". The meaning of the Internet itself is all computer networks that are interconnected using the Global Transmission Control Protocol/Internet Protocol Suite system standard or commonly referred to as TCP/IP. The development of the Internet has also influenced economic development in parts of the world. Various sales transaction that previously could only be done by way of face-to-face or market. After the presence of the internet is now very easy to make buying and selling. Sufficiently capitalized, the internet and the products are sold through internet. Buyer can see pictures of goods that are sold over the internet. Buying and selling over the Internet is known by the name of e-commerce.

Related to governance, the Internet also triggers the growth of transparency in the implementation of governance through e-government. As is the case with the management of public funds, health and various information provided by the government for the community posted on the internet that allows the public to know about any discourse given by the government. Complaints and suggestions from the public can be channeled through the internet and sent directly to parties related to the government so that people's appreciation can be channeled.

As reported by KOMINFO (Ministry of Communication and Information of the Republic of Indonesia). Internet users in Indonesia in 2017 reached 112 million users. This number puts Indonesia in the 6th position in the world in terms of internet users. It is undeniable that the progress of communication at this time is forcing the Indonesian people to use the internet so as not to miss very useful information from all over the world (www.kominfo.go.id). Understanding the internet in the era of globalization is very 
important. The socialization of E-Filing in cyberspace is one way for the Directorate General of Tax's E-Filing program to be quickly achieved.

Several previous studies on the influence of internet understanding of taxpayer compliance have been studied by Awaloedin and Maulana (2018) Oktaviani et al. (2018) the results of the study indicate that internet understanding influences taxpayer compliance. This research essentially integrates some of the research described above. The purpose of this study was to reexamine the effect of the application e-filing system to tax compliance in the SPT and to find out Internet understanding moderating the relationship between the applications of e-filing system to tax compliance.

\section{Literature review}

\subsection{Tax}

According to Soemitro and Sugiharti (2010) giving statements regarding taxes as follows: "People's contributions to the State treasury are based on the law (which can be forced) by not getting lead services (contra) which can be directly shown and used to pay public expenses". According to Law No. 28 of 2007 provides the following tax statement: "Taxes are mandatory contributions to the State owed by individuals or coercive entities." Based on this definition it can be concluded that taxes are mandatory contributions to the people governed by the law, without direct reciprocity services used to finance state households, namely expenditures that benefit the community.

\subsection{Notification Letter (SPT)}

According to Law No. 28 of 2007 article 1 number 11 gives a statement regarding the Notification Letter (SPT) as follows: "Notification Letter is a letter which by the taxpayer used to report the calculation and/or assets and obligations in accordance with the provisions of tax legislation." The obligation of taxpayers to submit notification is regulated in Law No.28 of 2007 Article 4 paragraph (1) as follows: "Taxpayers must fill out and submit notification letters correctly, completely, clearly, and signed "According to Mardiasmo (2011) giving statements regarding Notification (SPT) as follows: "The letter used by the taxpayer is to report tax calculations and/or payments, tax objects and/or non-tax objects, and/or assets and liabilities in accordance with the provisions of tax legislation".

Notification letters are letters that must be reported by taxpayers regarding the calculation of assets and liabilities in accordance with tax laws for a certain period or tax year. For taxpayers, the Notice serves as a means to report and account for the calculation of the actual tax payable and to report on:

1. Tax payments or settlements that have been carried out by themselves or through withholding or collecting other parties within 1 (one) tax year or tax year;

2. Income which is a tax object and/or not a tax object;

3. Assets and liabilities; and/or

4. Payment from withholding or collecting of withholding or collection of individuals or other bodies within 1 (one) tax period in accordance with the provisions of tax legislation.

Notification letters are broadly divided into two types:

1. A period notification is a notification letter for a period.

2. An annual notification letter is a notification letter for a tax year or part of a tax year.

\subsection{E Filing System}

According to PER-01/PJ/2014 a statement regarding the e-filing system is as follows: "Delivery Annual SPT which done online and in real time via the Internet on the website of the Directorate General of Taxes".

At present e-filing system facilities can only be enjoyed for reporting 2 types of tax returns, namely the Annual Personal Tax Return using Form $1770 \mathrm{~S}$ is a WP OP that has income from one or more employers, from other domestic countries, and/or is subject to Income Tax is final. and annual SPT that uses Form 1770SS is a WP OP that has income from only one employer with a gross income from work not more than Rp. 60,000,000 (sixty million rupiah) a year and have no other income except income in the form of bank interest and/or cooperative interest. 


\subsection{Taxpayer Compliance}

According to Pratama (2012) regarding compliant taxpayers, they are as follows: "The tax schedule determined by the Director General of Taxes as taxpayers who meet certain criteria can be given a preliminary refund of overpayment of taxes. Every year at the end of January the determination of compliant taxpayers is made".

Based on the Minister of Finance Regulation No. 192/PMK.03/2007 concerning Taxpayers with Certain Criteria in the Framework of Returning Overpayment of Tax Payments, Taxpayers with certain criteria which are subsequently referred to as Compliant Taxpayers are Taxpayers who meet the following requirements :

1. Timely submitting Notification Letter;

2. Do not have tax arrears for all types of taxes, except tax arrears that have obtained permission to pay in installments or delay tax payments;

3. The financial statements are audited by a Public Accountant or supervisory agency government finances with a reasonable opinion without exception for 3 (three) consecutive years; and

4. Has never been convicted of a criminal offense in the field of taxation based on a court decision that has had permanent legal force within the last five (5) years.

Measure Indicators the level of compliance required taxes that taxpayers fill with truthful, complete and correct Letter of Notification (SPT) in accordance with the provisions applicable and mandatory taxes time SPT and annual SPT. This is an important measure because with the taxpayer's submission by the taxpayer the taxpayer has made tax payments in accordance with the law.

\subsection{Internet understanding}

According to Sibero (2011) giving statements about the internet are as follows: "Internet (Interconnected Network) is a computer network that connects computers global. Internet also referred to as natural tissue that is a very broad network". The internet can also work the same as computer networks in general, as well as local networks and wide area computer networks. The Internet also uses a protocol of communication that the same is TCP/IP (Transmission Control Protocol/Internet Protocol).

According to the Big Indonesian Dictionary (KBBI), it gives a statement about understanding, which is to have a basic word of understanding, which means clever and truly understands the process, method, action (about a matter). Based on this understanding, it can be concluded that understanding the internet is understanding what the internet is and knowing how to use the internet. The benefits of the internet for daily life are:

1. Obtain information. The internet provides information that users need. With the internet, users can easily obtain various information.

2. Increase knowledge. The internet provides freedom of access to search and get the necessary knowledge.

3. Give speed to access it. The internet provides speed in accessing various information, knowledge and other interests.

\subsection{Hypothesis}

The hypothesis is a temporary conclusion regarding the relationship between two or more variables expressed in the form of a statement. The hypothesis is also a temporary answer because the answers given are only based on relevant theories, not yet based on empirical facts obtained from data collection.

Based on the above framework, the authors propose the following hypothesis:

$\mathrm{H}_{1}$ : e-Filing System Influences Taxpayer compliance.

$\mathrm{H}_{2}$ : Understanding the Internet moderated the effect of e-Filing System Implementation on Taxpayer Compliance.

\section{Methodology of research}


The data used in this study are primary data. Primary data is data obtained directly from the original source. Primary data in this study is the form of answers to a questionnaire of respondents. Data obtained from Individual Taxpayers and registered at KPP Pratama Jambi City in 2015-2018. The sample in this study was 100 respondents taxpayer Jambi city.

\subsection{Research Variables and Operationalization Variables}

Operationalization of variables is everything that will be the object of observation in research based on the observed properties. Operationalization of variables is needed to determine the types and indicators of related variables in this study.

The variables in this study are classified into two groups of variables namely the independent variable, dependent variable and moderating variable. Based on these variables, the variables that will be used in this study are independent variables, namely the application of e-filing system as an independent variable, compulsory compliance as dependent variable, and internet understanding as a moderating variable. Then the variables in this study include:

Table 1. Operationalization of Variables

\begin{tabular}{|c|c|c|}
\hline Variable & Indicator & Scale \\
\hline $\begin{array}{c}\text { System Implementation } \\
\text { E-Filing (X) }\end{array}$ & $\begin{array}{l}\text { 1. SPT reporting speed } \\
\text { 2. More efficient } \\
\text { 3. Faster calculation } \\
\text { 4. Ease of filling SPT } \\
\text { 5. Completeness of data filling SPT } \\
\text { 6. More environmentally friendly } \\
\text { 7. No hassle }\end{array}$ & Ordinal \\
\hline $\begin{array}{l}\text { Compliance with Submission of } \\
\text { Tax Returns WPOP }(\mathrm{Y})\end{array}$ & $\begin{array}{l}\text { 1. Compliance to register } \\
\text { 2. Compliance for depositing } \\
\text { Return Notification Letter (SPT) } \\
\text { 3. Compliance with calculations and } \\
\text { payment of tax due } \\
\text { 4. Compliance with payments } \\
\text { Arrears }\end{array}$ & Ordinal \\
\hline Internet Understanding (Z) & $\begin{array}{l}\text { 1. Obtaining information } \\
\text { 2. Add knowledge } \\
\text { 3. Access speed }\end{array}$ & Ordinal \\
\hline
\end{tabular}

\subsection{Moderated Regression Analysis}

Moderated Regression Analysis using an analytical approach that maintains sample integrity and basis for controlling the effect of moderating variables. Following is the regression equation to determine the types of moderating variables according to Imam (Ghozali, 2013):

$\mathrm{Yi}=\alpha+\beta 1 X i+\beta 1 X i * Z i+\varepsilon$

Information:

$\mathrm{Yi}=$ Taxpayer Compliance

$\alpha=$ Constant number

$\beta=$ coefficient of research equation

$X=$ Application of e-filling system

$\mathrm{Z}=$ type of moderator variable

$\varepsilon=$ Interference error

\section{Data Analysis Methods}

This research is a type of survey research by taking samples from population and using questionnaires as a primary data collection tool. The instrument used to collect the questionnaire is data in 
the form of statements. Determinants of values or score questionnaire using Likert scale, which converts the data qualitatively obtained into quantitative data. Likert scale is a method used to measure attitudes (Sugiyono, 2010).

The measurement used to assess the answer given is five (5) levels, namely a score of 1 (one) to 4 (four). The score is 1 for answers that strongly disagree, 2 for answers disagree, 3 for answers less disagree, 4 for answers agree and 5 for answers strongly agree. Statistical analysis regarding data modeling and decision making based on data analysis.

This study use data processing technique carried out using the WarpPLS Version 4 application program, which aims to examine the effect of independent and dependent variables as well as moderation variable. In other words, path analysis is an extension of multiple linear regression analysis in which use of regression analysis aims to estimate the causal relationship between variables (casual models) that have been predetermined based on theory. To see the evaluation of hypotheses, it can be removed from the output results of the WrapPLS application in the view path coefficients and P-values section. Ghozali and Latan (2014) stated that in evaluating the fit model in WrapPLS, it must follow the criteria that have been recommended.

\section{Results and Discussions}

This research uses partial least square (PLS) method. Evaluations in PLS include evaluating inner models or structural models. Structural model analysis can be done by evaluating the results of the estimated path coefficient parameters and their level of significance. The results of the significant test of the relationship between paths and moderation relationships can be seen in this figure which is a full model picture of this study:

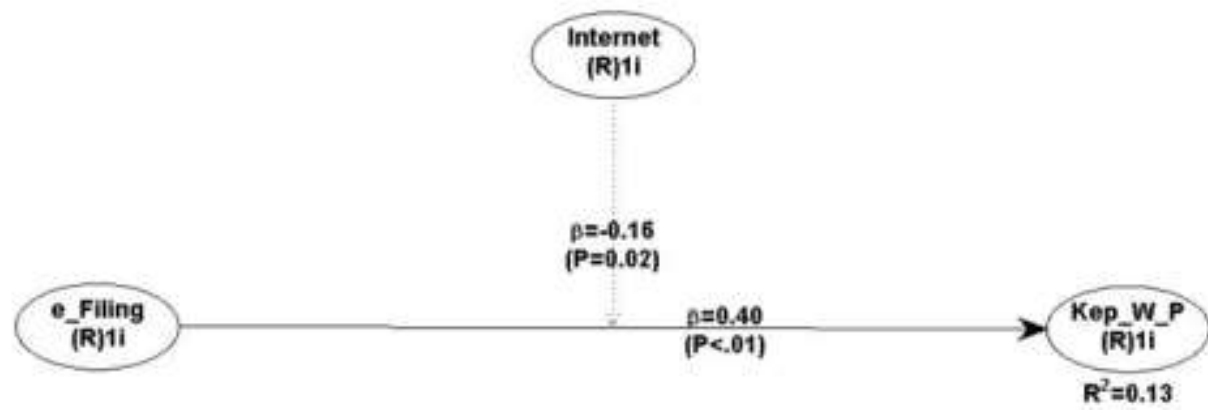

Source: Out Put WrapPLS

Figure 1. Full Model Research

The picture above explains the relationship between variables in this study as a whole, where there is a large relationship between variables. This can be explained based on the value that indicates the direction of the relationship between variables. Based on the picture above the value of $R$-squared $\left(R^{2}\right)$ relationship role e-filing of the compliance of the taxpayer has a value of 0.13 or by $13 \%$ this means that the variable E-Filing can affect the compliance of taxpayers by $13 \%$, while $87 \%$ at the influence of other variables. The following can be seen an explanation of the goodness of the model built (fit model) in this study as in Table 2 below:

Table 2. The model built (fit model)

\begin{tabular}{|c|l|c|c|}
\hline Criteria & \multicolumn{1}{|c|}{ Cut of Value } & Results & Evaluation \\
\hline Average path coefficient (APC) & P-value $\leq 0.05$ & 0.377 & Weak \\
\hline Average R squared (ARS) & P-value $\leq 0.05$ & 0.558 & Fit Model \\
\hline Average adjusted R-squared (AARS) & P-value $\leq 0.05$ & 0.110 & Weak \\
\hline Average block VIF (AVIF) & $\leq 3,3$, but the value $\leq 5$ is still acceptable & 5,213 & Fit Model \\
\hline Tenenhaus GoF ( GoF ) & $\geq 0,10, \geq 0,25$, and $\geq 0,36$ (small, medium, and large) & 0.759 & Big \\
\hline $\begin{array}{c}\text { Sympsonsparadox ratio (SPR) } \\
\text { R- squared contribution distribution } \\
\text { (RSCR) }\end{array}$ & Ideally $=1$ but the value $\geq 0.7$ is still acceptable & 0.556 & Fit Model \\
\hline Idatistical suppression ratio (SSR) & Must be $\geq 0.7$ & 0.919 & Fit Model \\
\hline
\end{tabular}


Overall it can be seen from Table 2 above that of all the criteria fulfilled, even though there are several criteria that have a weak relationship. Results Average Adjusted RSquared (AARs), Average RSquared (ARS), and the Average Path Coefficient (APC) as a whole is weak, meaning the path analysis model were built weak between the relationships of variable. Calculation of Average B lock VIF (AVIF) as a whole has a value below the threshold (cut of value) with a value of 1.470 means that the model built is fit model in other words the model built does not occur multicollinearity.

The Tenenhaus GoF (Gof) result of 0.362 can be said to be the strength of the model's dedication that was built in predicting the relationship between variables (the path that was built) in this study is large or strong. Value Simpsons Paradox Ratio (SPR) of 0.500 means that the model is built free Simpsons paradox or not the problem of causality in the study, while R- squared contribution ratio worth 0.799 means there is no contribution R-squared negative in this study, as well as the value of sstatistical suppression ratio of 1,000 can be interpreted that the model in this study is free from statistical suppression.

The interpretation of the fit model above depends on the purpose of the study. The research aims only to test the hypothesis, where each path represents the hypothesis, then the evaluation of model fit is less important, but conversely if the purpose of the analysis is to determine a model that is fit with the original data, then the evaluation of model fit becomes important and useful for measuring the quality of the model. When evaluating the fit of the model must follow the criteria that have been recommended.

\subsection{Path Evaluation Results}

The results of the evaluation of hypotheses based on the structural model that was built were carried out by looking at the significant value of $\mathrm{P}$-value to determine the effect between variables based on the hypotheses built through the resampling procedure. According Ghozali and Latan (2014), hypothesis evaluation can be seen from the results output applications WrapPLS on the viewPath coefficients and Pvalue.

Significant values were used with the P-value of 0.10 (significance level $=10 \%$ ), 0.05 (significance level $=5 \%$ ) and 0.01 significance level $=1 \%$ ). This study uses a P- value of 0.05 (significance level $=5 \%$ ). The results of the road evaluation are presented in Table 3:

Table 3. Path Evaluation Results

\begin{tabular}{|l|c|c|c|}
\hline \multirow{2}{*}{ Path } & \multicolumn{2}{|c|}{ Direct effect } & \multirow{2}{*}{ Conclusion } \\
\cline { 2 - 3 } & Path Coefficients & P- value & \\
\hline E-Filing -> Kep_W_P & 0.395 & 0.001 & Accepted \\
\hline E-Filing * Internet ->Kep_W_P & $-0,158$ & 0.020 & Rejected \\
\hline
\end{tabular}

Source: Processed data are used in this thesis (Output WarpPLS 5.0)

Based on Table 5, first path variable relationship e-filing of the compliance of mandatory tax has a value of path coefficients of 0.095 and the value of $P$ value of 0.001 means that the e-filing variable significancy positive against compulsory taxes and first hypothesis accepted. Results lanes to two variable correlations e-filing towards compliance taxes in moderation with internet understanding variables indicate the value of the path coefficients of -0.158 and $P$ value of 0.020 means that the variable value is not proven internet understanding moderated the relationship of e-filing variable to compulsory taxes and the second hypothesis was rejected.

\subsection{Discussions and conclusions}

In this discussion will explain the relationship between independent variables to the dependent variable by including hypothesis testing and data relating to the company that is sampled in the study.

\subsubsection{The Effects of E-Filing on Taxpayer Compliance}

The results showed e-filing variable had a positive significant effect on taxpayer compliance. It has been suggested that the policy of e-filling can improve taxpayer compliance. The results of this study are in 
accordance with previous studies conducted by Erawati and Ratnasari (2018) and Ismail et al. (2018) the the application of E-Filing has a positive significant effect on taxpayer compliance. The implementation of the E-Filing policy has proven in increasing the number of taxpayer compliance, in 2017 the taxpayer target increased to $89 \%$ of the 2017 APBNP. This is a evidence of the positive impact of the e-filing policy (source: www.pajak.go.id).

The logical relationship can be stated that the E-Filing policy issued by the Directorate General of Taxes will increase taxpayer compliance in carrying out its obligations. Ease of payment of taxes and features that are easily understood by taxpayers on E-Filing services can increase taxpayer compliance.

\subsubsection{The effect of internet understanding as a moderating relation between e-filing and Taxpayer Compliance}

Based on the results of the study showed that the internet understanding variable as a moderating relation between e-filing and taxpayer compliance was not proven. Overall it can be interpreted that the relation between E-Filing policy and internet understanding has proven unable to strengthen taxpayer compliance. In accordance with research conducted by Lado and Budiantara (2018) that the internet understanding variable as a moderating relationship between e-Filing and taxpayer compliance is not proven. Logical relationships can be argued that the understanding of the Internet cannot strengthen or improve relations policies between e-filing and taxpayer compliance in Jambi City.

\section{References}

1. Awaloedin, D. T., and Maulana, M. A. (2018). Effect of E-Filling System Implementation, Internet Understanding and Taxpayer Awareness on the Compliance of Depok Cimanggis Primary Taxpayers. Journal of Information Engineering 7 (2).

2. Erawati, T., and Ratnasari, R. (2018). The Effect of E-Filling Implementation on Taxpayer Compliance in Delivering Annual Spt with Service Quality Satisfaction as Intervening Variables (Empirical Study in Gunung Kidul Regency). Journal of Accounting 6 (01).

3. Ghozali, I. (2013). Multivariate Analysis Application with the IBM SPSS 21 Program. Semarang: Diponegoro University Publisher Agency.

4. Ghozali, I., and Latan, X. V. (2014). Partial Least Squares Concepts, Methods and Applications Using the WarpPLS 4.0 Program. Semarang: Diponegoro University Publisher Agency.

5. Ismail, J., Gasim, and Amalo, F. (2018). Effect of E-Filing System Implementation on Taxpayer Compliance with Socialization as Moderation Variable (Case Study on KPP Pratama Kupang). Journal A kuntansi 5 (3).

6. Lado, Y. O., and Budiantara, M. (2018). Effect of E-Filling System Implementation on Civil Servants Taxpayer Personal Compliance with Internet Understanding as Moderating Variables (Case Study at the Department of Industry and Trade DIY). JRAMB, Accounting Study Program, Faculty of Economics, UMB Yogyakarta 4 (1).

7. Mardiasmo. (2011). Taxation Revised Edition, Yogyakarta Andi Publisher.

8. Oktaviani, R. M., Sunarto, S., and Lita, N. (2018). Understanding the Internet as a Moderating Application of the E-Filling System against Taxpayer Compliance. Proceedings of SENDI_U 2018.

9. Sibero, A. F. K. (2011). The Scriptures of Web Programming. Jakarta: Mediakom

10. Soemitro, R., and Sugiharti, D. K. (2010). Principles and Basis of Taxation (1) (Revised Edition). Bandung: Refika Aditama.

11. Sugiyono. (2010). Qualitative Quantitative Research Methods and R\&D Bandung: Alfabeta

12. Suherman, M., Almunawwaroh, M., and Marliana, R. (2015). The Effect of E-Filing Application on Taxpayer Compliance in Submitting Annual Tax Returns at the Tasikmalaya City Tax Service Office. Accounting, Auditing \& Information Research Media 15 (1). 